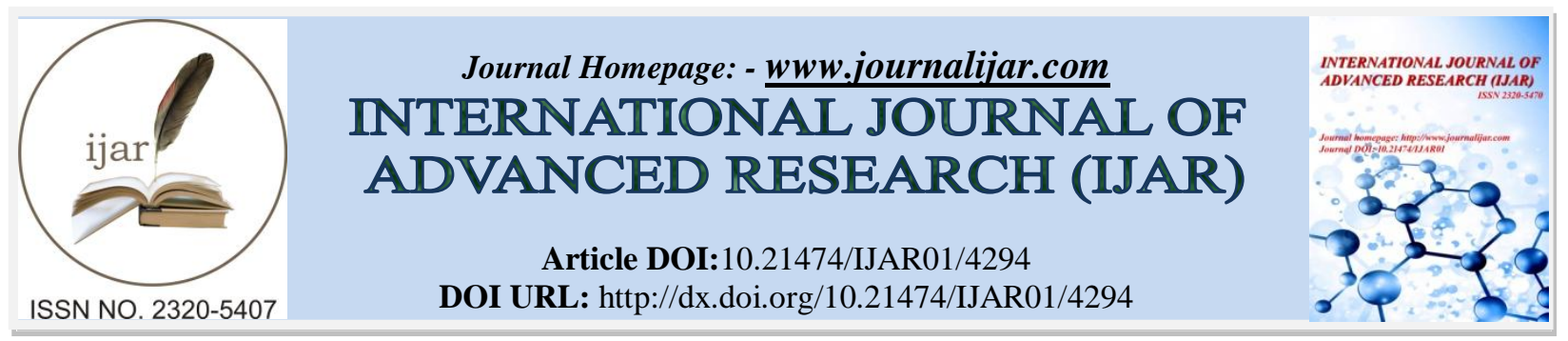

RESEARCH ARTICLE

\title{
SHRINKAGE AND PERMEABILITY PROPERTIES OF SELF - COMPACTING CONCRETES CONTAINING RECYCLED COARSE AND/OR FINE GLASS AGGREGATES.
}

\author{
Osamah Mohammed Al-Kerttani ${ }^{1,2}$ and Rahman Al-Bawi ${ }^{1,3}$. \\ 1. Civil Engineering Department, Gaziantep University, 27310 Gaziantep, Turkey. \\ 2. Civil Engineering Department, Al-Mustansiriyah University, Baghdad, Iraq. \\ 3. Civil Engineering Department,Diyala University, Diyala, Iraq.
}

\section{Manuscript Info}

Manuscript History

Received: 26 March 2017

Final Accepted: 27 April 2017

Published: May 2017

Key words:-

glass cullet, permeability properties, recycled glass aggregate, self-

compacting glass concrete, and shrinkage.

\section{Abstract}

The paper presented herein was carried out to investigate the shrinkage and permeability characteristics of self -compacting concretes contained recycled green glass aggregate. The total binder content was $570 \mathrm{~kg} / \mathrm{m}^{3}$ and at a water-binder material $(\mathrm{w} / \mathrm{b})$ ratio of 0.35 . In addition, fly ash (FA) was used in concrete at $20 \%$ of total binder content. A total of 15 SCCs in addition to control mixture were produced and classified into three series. Each series consist of five ratios of recycled green glass aggregate as a replacement of natural aggregate, the ratios of replacement was $20 \%, 40 \%, 60 \%, 80 \%$, and $100 \%$ by the weight.

Permeability properties of SCCs were tested in terms of chloride ion permeability, water sorptivity, and gas permeability at 28 days. Also, physical properties were examined through drying shrinkage accompanied by the water loss and restrained shrinkage of SCCs was monitored over 50 days of drying period because these physical tests became a constant after 20 days of casting. Test results showed that incorporating of recycled green coarse and/or fine glass aggregates negatively affected on the permeability properties of SCCs. While, the drying shrinkage and restrained shrinkage cracking of recycled fine glass aggregate (RFGA) concretes had significantly improves unlike the use of recycled coarse glass aggregate (RCGA) and utilized both fine and coarse recycled glass aggregate when replacement ratio exceeding $40 \%$. However, all the results which obtained when using recycled glass aggregate were less than that when using natural aggregate (NA). The same results were observed on the time of initiate cracking.

Copy Right, IJAR, 2017,. All rights reserved.

\section{Introduction:-}

Concrete is a heterogeneous material consisting of aggregates bond with cement paste. Its performance affected by many properties such as its constituent materials, mixing method, environmental exposure, placement and curing.

Self -compacting concrete is considered as a new type of high performance concrete which characterized by consolidating without any vibration and its ability to flow due to its own weight. Self -compacting concrete have high quality structures and low honey- comb construction due to high filling ability of SCC [1]. 
Aggregate play a significant role in mechanical, and durability properties of SCCs because aggregate occupy 60$70 \%$ of SCCs volume.

Conserve natural resources and reduce demand for valuable landfill space leads to thinking about waste recycling. The big problem around the world is discarded beverage glass bottles. In all countries, large proportions of solid waste consist of waste glass, and the major environmental problem is recycling the glass [2].

Among many types of solid waste, glass has been popular studied as a replacement for coarse, fine aggregate and even cement. Because of its chemical composition and physical constituents, recycle waste glass is considered as good replacement as sand, especially important for places lacking in natural resource and dealing with disposal of wastes [3].

According to United Nations 7\% of solid waste which is about 200 million tons is glass in all over the world. The current solution is still to landfill most of the waste glass. Since the glass is not biodegradable, landfills do not provide an environment-friendly solution [2].

In Turkey, glass recycling rate was only $25 \%$ in 2009 because, insufficient funding for recycling programs and low societal awareness of sorting recyclables also, the absence of a good-organized system for recoverable waste [4].

Glass cullet is pieces of broken glass in different colors which have hardly any recycling potential. Glass aggregate is a good waste material to utilize as aggregate due to low water absorption. The hardness of glass also gives concrete high abrasion resistance. Fine glass aggregate has pozzolanic reactivity lead to decrease cement content. Thus, the cost of concretes decreases [5]. Also, light weight concrete can be produced by using glass after special process [6].

Kou and Poon [7]tested self-compacting concrete by using recycled glass as a partial replacement of fine aggregate with $10 \%, 20 \%$ and $30 \%$, and granite aggregate with maximum size of $10 \mathrm{~mm}$ in proportions of $5 \%, 10 \%$ and $15 \%$. Also fly ash was used to inhibit the activity of alkali-silica reaction. For all mixes the initial slump flow were designed to be $750 \mathrm{~mm}$. It was concluded that the drying shrinkage decreased and resistance to chloride ion penetration increased with increasing the amount of recycled glass in self-compacting concrete since the waste recycled glass had less porosity than river sand and natural granite.Dhiret al. [8] reported that when the fine glass became coarser the shrinkage of concrete became less due to decrease in the amount of absorption of water.

Wang and Huang [1] said that when the amount of glass increased to $30 \%$ the durability characteristics of selfcompacting glass concrete improved by reducing the chloride ion penetration to less value which was less than 100 coulombs (C) at 180 days, according to authors this behavior can be attributed to the glass sand fill the internal pores and reduce the ability of ions to penetrate.Ling et al. [9] investigated the feasibility of using $100 \%$ recycle glass as sand in architectural white cement mortar. Metakaolin was used as a partial replacement of white cement, the water/binder ratio was 0.4 for all the mixtures and the amount of superplasticizer was varied to produce highly workable recycled glass self-compacting white cement mortar. The results showed that the initial surface absorption (in first $30 \mathrm{~min}$ ) and final water absorption (after 96 hours) increase with the increased the amount of recycled glass because of larger pore volumes in the mortars containing glass since that glass has larger particle size and angular shape. It was found that the drying shrinkage was decreased with increase the recycled glass replacement until the age of 112 days, this behavior due to low absorption of recycled glass.

So far much work has been focused on the fresh and mechanical properties of self-compacting glass concretes (SCGCs), neglecting durability properties like permeability and shrinkage. Therefore, the main focus of this study is to assess the influence of glass on the some durability properties of SCCs made with recycled fine glass and/or recycled coarse aggregate glass to provide further information on the current application requirements.

The permeability was examined through rapid chloride penetration (RCPT), water sorptivity, and gas permeability tests at the age of 28 days. Also, physical properties were tested such as drying shrinkage, accompanied weight loss, and restrained shrinkage of SCCs were observed until the age of 50 days of drying. 


\section{Experimental study:- \\ Materials:-}

Ordinary Portland cement (CEM I 42.5 R), conforming to the TS EN 197 [10] (mainly based on the European EN 197-1) was used in all SCCs mixes. Type C fly ash FA, supplied from Çatalağzı Thermal Power Plant, Zonguldak, Turkey, was utilized as cement replacement materials at a $20 \%$ replacement level by weight of cement. Chemical composition and physical properties of the cement and FA are given in Table 1. High Range Water Reducing Admixture (HRWRA) with a specific gravity of 1.07 was used to achieve the target workability.

In this study, recycled green glass (RGG) was used at different replacement levels by weight of natural aggregates (NAs). In this regard, recycled fine glass aggregates (RFGAs) had a particle size of 0-4 mm and specific gravity of 2.53. While, recycled coarse glass aggregates (RCGAs) were utilized with a particle size of 4-11.2 mm and specific gravity of 2.55. In effect, 24-hour absorption capacity of RGG was too little and it could be neglected. The chemical analysis of RGG is listed in Table 3. The physical properties of RGG aggregates and NAs were determined according to ASTM C127 [11]. Moreover, river sand natural coarse aggregates (NCAs) and natural fine aggregates (NFAs) conforming to the TS 706 EN 12620-A1 [12] were used. The maximum size of NCAs and NFAs were 16 and $4 \mathrm{~mm}$ whilst 24 -hour absorption capacity was $0.77 \%, 1.09 \%$ respectively. Moreover, the physical observation of RGG had exhibited smooth surfaces, angular shape and sharp edge. Sieve analysis and physical properties of the aggregates are shown in Table 2.

\section{Concrete mixture design and casting:-}

Three different series of self-compacting glass concrete (SCGC) mixtures were designed with a constant water/ binder material $(\mathrm{w} / \mathrm{b})$ ratio of 0.35 and binder materials content of $570 \mathrm{~kg} / \mathrm{m}^{3}$. The $1^{\text {st }} \operatorname{mix}(\mathrm{M} 1)$ was the reference .While; the $1^{\text {st }}$ series of mixtures was designed to replace natural fine aggregates (NFAs) by recycled fine glass aggregates (RFGAs) in different proportions (20,40,60, 80, and100) \% by the weight of NFAs. The replaced of natural coarse aggregates (NCAs) with recycled coarse glass aggregates (RCGAs) was done in the $2^{\text {nd }}$ series with $(20,40,60,80$, and100) \% by the weight of NCAs. While; series III was included RFGAs \& RCGAs instead of NFAs \&NCAs at levels of $(20,40,60,80$, and100) \% by the weight of NFAs \&NCAs. Therefore, 16 different SCGCs mixtures were designed as given in Table 4.

The concrete mixes were designed and produced in a pan-type mixer with a 30 L capacity according to ASTM C192 [13]. In the production of self-compacting concretes, the mixing sequence and duration are very important. Thus, the procedure for batching and mixing proposed by Khayat et al. [14] was employed to supply the same homogeneity and uniformity in all mixtures. The batching sequence consisted of homogenizing the natural and glass(fine and coarse) aggregates for $30 \mathrm{sec}$. in a rotary planetary mixer, then adding about half of the mixing water into the mixer and continuing to mix for one more minute. Thereafter, the natural and recycled aggregates were left to absorb the water in the mixer for $1 \mathrm{~min}$. After cement and fly ash were added, the mixing was resumed for another $1 \mathrm{~min}$. Finally, the superplasticizer with remaining water was introduced, and the concrete was mixed for 3 min and then left for a 2 min rest. Eventually, the concrete was mixed for additional 2 min to complete the mixing sequence. Then, for each mix specimens cast from a typical mixture consisted of two $\varnothing 100 \times 200 \mathrm{~mm}$ cylinders for determining chloride ion permeability and sorptivity index, one $\varnothing 150 \times 300 \mathrm{~mm}$ for gas permeability, three $70 \times 70 \times 280 \mathrm{~mm}$ for free shrinkage and weight loss, and one specimen for restrained shrinkage cast around steel mould with $\varnothing 305 \mathrm{~mm}$, the height and thickness of specimen is 104 and $35 \mathrm{~mm}$ respectively. All samples were kept in curing room with $100 \%$ relative humidity and temperature of $20^{\circ} \mathrm{C}$. After that, the specimen were demoulded $24 \mathrm{~h}$ after casting and stored in water tank at $20 \pm 2{ }^{\circ} \mathrm{C}$ until the time of testing which is 28 days. While, after demoulded the specimen for drying and restrained shrinkage were exposed to drying in a humidity room at $23 \pm 2{ }^{\circ} \mathrm{C}$ and $50 \pm 5 \%$ relative humidity, as per ASTM C157[15] for about 50 days.

\section{Test procedures:-}

Resistance to chloride ion penetration:-

Rapid Chloride Permeability Test (RCPT) was used to determine the resistance of concrete to the penetration of chloride of ions according to ASTM C1202 recommendations [16]. In this test the resistance of concrete to chloride ions penetration has been measured for $6 \mathrm{~h}$. However, Kanellopoulos et al.[17] said that such relation is not perfect. The resistivity is measured in terms of the total electric charge (measured in coulombs, C) passed through the specimens, and these measurements are used to classify mixtures as shown in Table 5. Figure 2 represents the schematic presentation and photographic view of the test setup for RCPT. 
The RCPT was carried out at the age of 28 days; two samples were tested together for each mix. After curing, samples of $50 \mathrm{~mm}$ thick cut from middle portion of $\varnothing 100 \times 200 \mathrm{~mm}$, after that the samples were allowed to surface dry in air. A rapid setting coating was applied onto lateral surface of samples to avoid evaporation of water. Later, the samples were put in vacuum saturation for $2 \mathrm{~h}$. Then, the samples were put in water in a room at $20^{\circ} \mathrm{C}$ and $50 \%$ relative humidity for $18 \pm 2 \mathrm{~h}$. Finally, the disks were transferred to test cell which one face was subjected to $0.3 \mathrm{~N}$ $\mathrm{NaOH}$ solution and the other face was subjected to $3 \% \mathrm{NaCl}$ solution as shown in Figure 3 . Then, a direct voltage of $60 \pm 0.1 \mathrm{~V}$ was applied across the faces for $6 \mathrm{~h}$.the measurement was taken every $30 \mathrm{~min}$. After the end of the test, current (in amperes) versus time (in seconds) were plotted for every samples and the area underneath the curve was integrated to obtain the charge passed (in coulombs).

\section{Sorptivity Index:-}

The sorptivity test measures the rate at which water is drawn into the pores of concrete. Three samples for each mix with diameter of $100 \mathrm{~mm}$ and $50 \mathrm{~mm}$ thick were cut from $\varnothing 100 \times 200 \mathrm{~mm}$ cylinders were used for this test. Before the test began, the samples were put in an oven at temperature of $105 \pm 5{ }^{\circ} \mathrm{C}$ until a constant mass was achieved, and then the samples were allowed to cool to ambient temperature in a sealed container. After that, the sides of samples were coated with sealing material as illustrated in Figure 3.

The water sorptivity test was carried out by placing the samples on glass rods in a pan such that their bottom surface up to a height of $3 \mathrm{~mm}$ is in contact with water. This procedure was considered to allow free water movement through the bottom surface. The samples were removed from the pan and weighed at different time intervals up to 1 $\mathrm{hr}$ to evaluate the mass gain. The volume of water absorbed was calculated by dividing the mass gained by the nominal surface area of the sample and by the density of water. These values were plotted against the square root of time. The slope of the line was defined as the sorptivity coefficient of concrete. The test was conducted at the ages of 28 days. The average of three samples represents the sorptivity index.

\section{Gas permeability test:-}

The coefficients of apparent oxygen gas permeability determined according to RILEM [18] on completely dry samples. For this test, after 28 days curing two samples for each mix were prepared, with $\varnothing 150 \times 50 \mathrm{~mm}$ cut from the middle section of $\varnothing 150 \times 300 \mathrm{~mm}$ cylinders. Before the test began, the samples were put in an oven at temperature of $105 \pm 5{ }^{\circ} \mathrm{C}$ until a constant mass was achieved, then the samples were allowed to cool to ambient temperature in a sealed container. After that, the samples were placed in the test device cell as shown in Figure 4.

After putting the sample in the cell and assembling the apparatus, Build up a minimum lateral pressure of 7 bar $(0.70$ $\mathrm{MPa})$ on the rubber tube. Then, the samples were subjected to air pressure starting from $1.5 \mathrm{bar}(0.15 \mathrm{MPa})$ to $5 \mathrm{bar}$ $(0.5 \mathrm{MPa})$ with increasing rate of $0.5 \mathrm{bar}(0.05 \mathrm{MPa})$. Take the time measurement for each pressure and always started the time measurement when the bubble is at the lowest marking of the calibrated tube. After that, apply the following equation on each sample to find out apparent gas permeability, and then the average of two samples was taken:

$\mathrm{K}_{\mathrm{i}}=2 \mathrm{P}_{2} \mathrm{QL} \mu / \mathrm{A}\left(\mathrm{P}_{1}-\mathrm{P}_{2}\right)^{2} \quad$ Where:-

$\mathrm{K}$ : Gas permeability coefficient $\left(\mathrm{m}^{2}\right) \quad \mathrm{P}_{1}$ : Inlet gas pressure $\left(\mathrm{N} / \mathrm{m}^{2}\right)$

$\mathrm{P}_{2}$ : Outlet gas pressure $\left(\mathrm{N} / \mathrm{m}^{2}\right) \quad$ A: Cross-sectional area of the sample $\left(\mathrm{m}^{2}\right)$

L: Height of sample $(\mathrm{m}) \quad \mu$ : Viscosity of oxygen $\left(2.02 \times 10^{-5} \mathrm{Nsn} / \mathrm{m}^{2}\right)$

Q: Rate of flow of air bubble $\left(\mathrm{m}^{3} / \mathrm{sn}\right)$

\section{Drying shrinkage and weight loss:-}

Three prisms of 70x70x280 mm were prepared to determine drying shrinkage and weight loss of SCGCs according to ASTM C157[15].

After demoulded, the gage length was fixed on each sample by means of the glued pins on the face of samples. The length change was determined by using a dial gage extensometer with $200 \mathrm{~mm}$ gage length and 0.002 strains for measurement. Measurement were applied every $24 \mathrm{~h}$. for the first 3 weeks after that 3 times a week. At the same time, measurements of weight loss were implemented for each sample. After the gage length was fixed on each sample by the glued pins on the face of prisms, its initial weight was recorded to monitor the weight loss during drying period. Then, the prisms samples were put in drying room at $23 \pm 2{ }^{\circ} \mathrm{C}$ and $50 \pm 5 \%$ relative humidity for 50 days. The test results for each property were evaluated by averaging the measurement of three prism samples. 


\section{Restrained shrinkage cracking:-}

In this study, the ring shaped samples were used so as to determine the shrinkage encouraged cracking of SCCs.

After the samples were demoulded, the top surface of concrete ring was covered with silicone rubber, so that drying would be permitted only by the outer circumferential surface Figures 6 (a, and b). Measurements were taken in the drying room at $23 \pm 2{ }^{\circ} \mathrm{C}$ and $50 \pm 5 \%$ relative humidity. To measure the crack widths on ring samples, a special microscope setup was used [19 and 20].

The crack widths were the average of measurments, one at the top of the crack, the second at the center , and the thired at the bottom of the crack as shown in Figure 5 (a).

Table 1:-Chemical compositions andPhysical properties of Portland cement and fly ash.

\begin{tabular}{|c|c|c|}
\hline Analysis Report (\%) & Cement & Fly ash \\
\hline $\mathrm{CaO}$ & 63.84 & 2.24 \\
\hline $\mathrm{SiO}_{2}$ & 19.79 & 57.2 \\
\hline $\mathrm{Al}_{2} \mathrm{O}_{3}$ & 3.85 & 24.4 \\
\hline $\mathrm{Fe}_{2} \mathrm{O}_{3}$ & 4.15 & 7.1 \\
\hline $\mathrm{MgO}$ & 3.22 & 2.4 \\
\hline $\mathrm{SO}_{3}$ & 2.75 & 0.29 \\
\hline $\mathrm{K}_{2} \mathrm{O}$ & - & 3.37 \\
\hline $\mathrm{Na}_{2} \mathrm{O}$ & - & 0.38 \\
\hline Loss on ignition & 0.87 & 1.52 \\
\hline Specific gravity & 3.15 & 2.04 \\
\hline Specific surface area $\left(\mathrm{m}^{2} / \mathrm{kg}\right)$ & 326 & 379 \\
\hline
\end{tabular}

Table 2:-Physical properties of NAs and RGAs

\begin{tabular}{|c|c|c|c|c|}
\hline \multirow{2}{*}{$\begin{array}{c}\text { Sieve size } \\
\mathrm{mm}\end{array}$} & \multicolumn{2}{|c|}{ NAs } & \multicolumn{2}{c|}{ RGAs } \\
\cline { 2 - 5 } & NFA & NCA & 100 & RCGA \\
\hline 16 & 100 & 100 & 100 & 100 \\
\hline 8 & 100 & 30.4 & 100 & 0.0 \\
\hline 4 & 100 & 0.0 & 51.57 & 0.0 \\
\hline 2.0 & 58.13 & 0.0 & 30.89 & 0.0 \\
\hline 1.0 & 37.2 & 0.0 & 10.63 & 0.0 \\
\hline 0.5 & 24.24 & 0.0 & 3.43 & 0.0 \\
\hline 0.25 & 8.7 & 0.0 & 3.03 & 5.76 \\
\hline Fineness modulus & 2.72 & 6.01 & 2.53 & 2.55 \\
\hline Specific gravity & 2.39 & 2.69 & & \\
\hline
\end{tabular}

Table 3:-Chemical compositions of recycled glass aggregate

\begin{tabular}{|c|c|}
\hline Component & Green glass cullet \\
\hline $\mathrm{SiO}_{2}$ & 71.907 \\
\hline $\mathrm{Al}_{2} \mathrm{SO}_{3}$ & 2.242 \\
\hline $\mathrm{Na}_{2} \mathrm{O}+\mathrm{K}_{2} \mathrm{O}$ & 9.577 \\
\hline $\mathrm{CaO}+\mathrm{MgO}$ & 15.597 \\
\hline $\mathrm{SO}_{3}$ & 0.222 \\
\hline $\mathrm{Fe}_{2} \mathrm{O}_{3}$ & 0.011 \\
\hline $\mathrm{Cr}_{2} \mathrm{O}_{3}$ & 0.301 \\
\hline $\mathrm{P}_{2} \mathrm{O}_{5}$ & 0.056 \\
\hline $\mathrm{K}_{2} \mathrm{O}$ & 0.533 \\
\hline $\mathrm{TiO}_{2}$ & 0.063 \\
\hline $\mathrm{SrO}^{\mathrm{ZrO}}$ & 0.010 \\
\hline & 0.014 \\
\hline
\end{tabular}




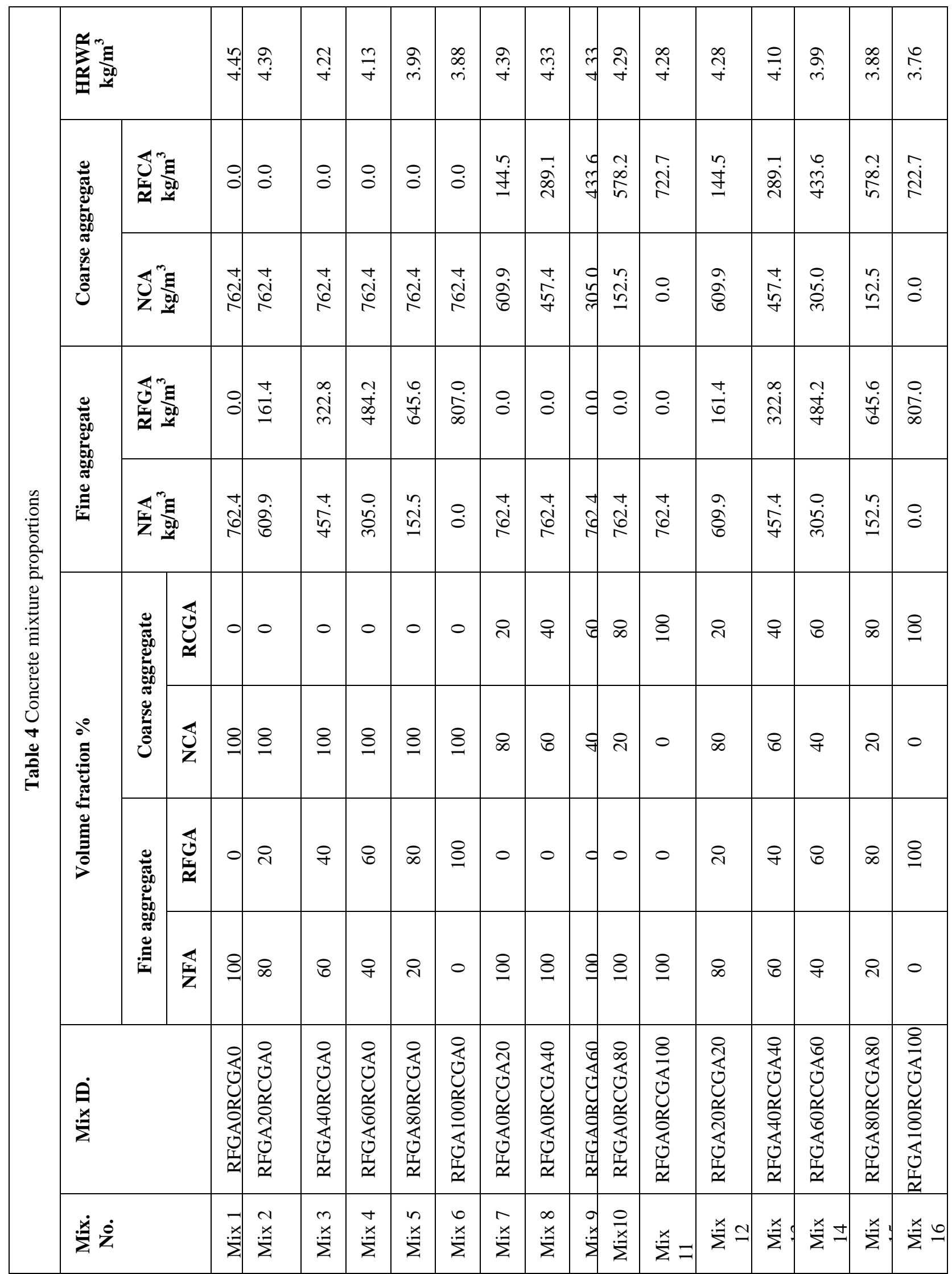




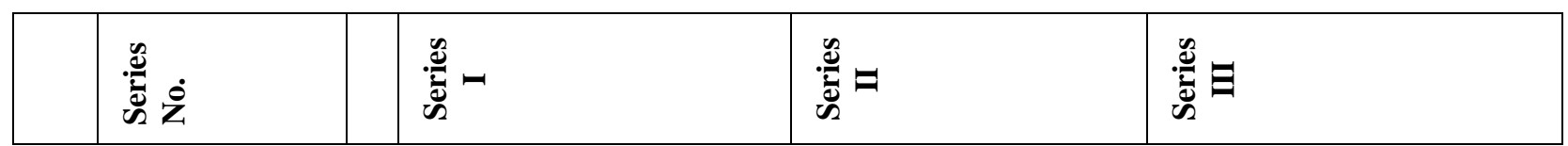

Table 5:- Chloride ion penetrability based on charge passed according to ASTM C1202 [9].

Charge passed $Q$ Chloride ion penetrability

$$
>4000
$$

$2000-4000$

$1000-2000$

$100-1000$

$<100$

High

Moderate

Low

Very low

Negligible
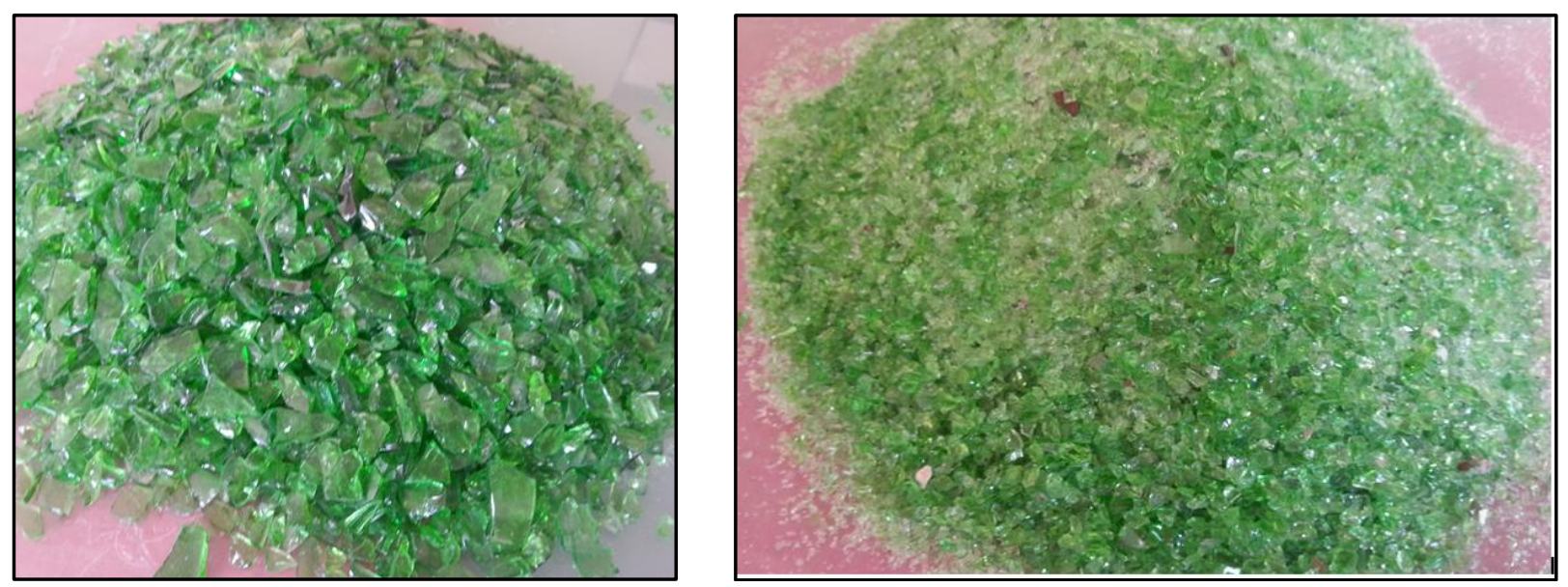

Fig. 1:-Recycled Glass Coarse and Fine Aggregate.

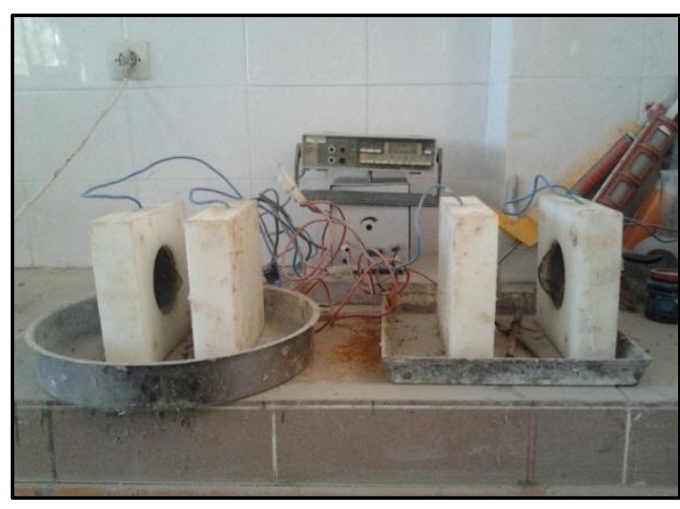

(a)

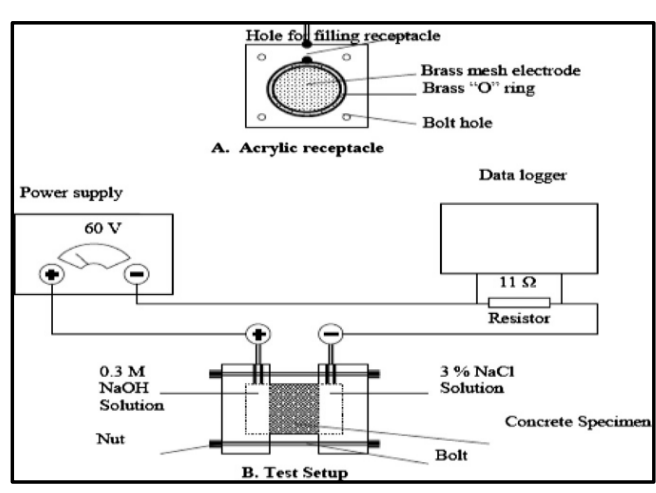

(b)

Fig 2:-RCPT test setup: (a) photographic view of the RCPT test setup and (b) schematic presentation of the test setup for RCPT. 


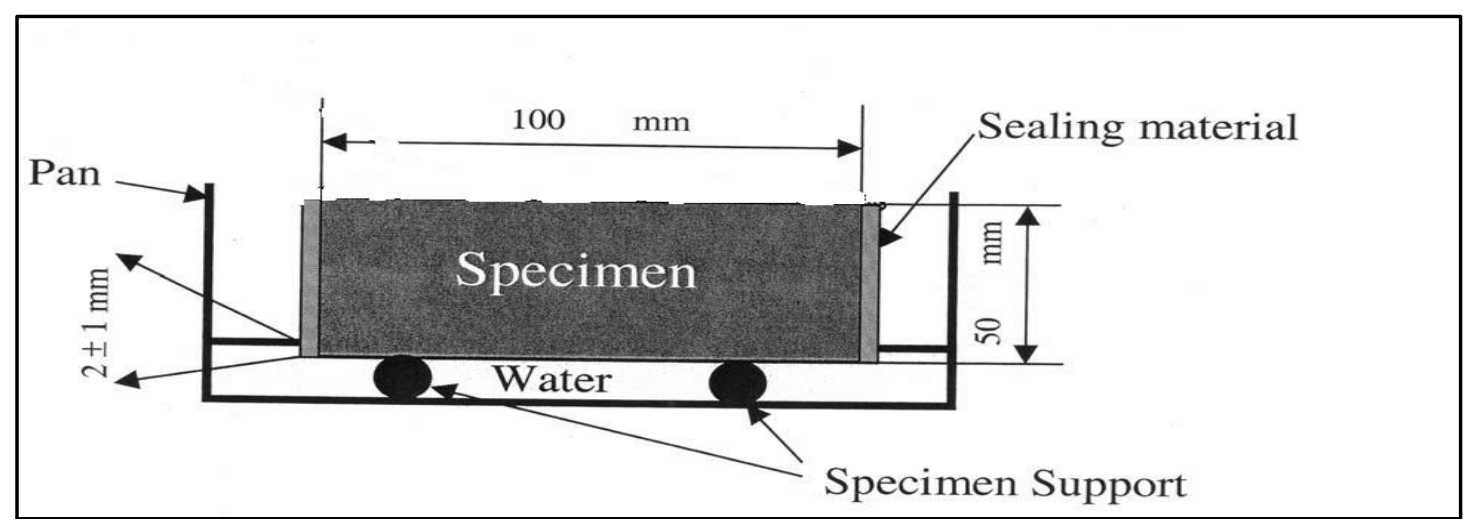

Fig3:-Schematic of the water sorptivity measurement.

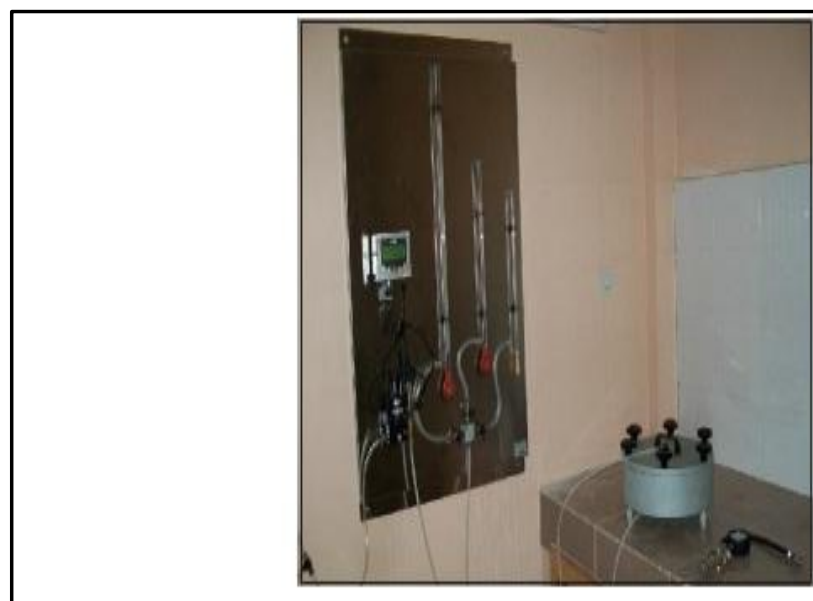

(a)

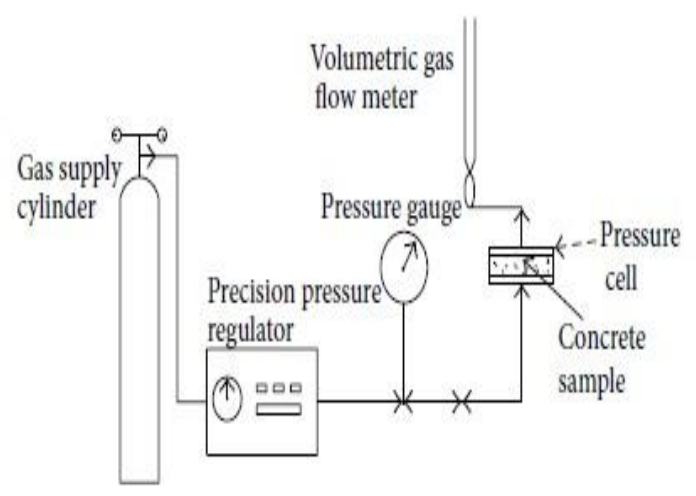

(b)

Fig4:-(a)Photographic view of the gas permeability test set up, (b) Schematic presentation of the gas permeability test set up.
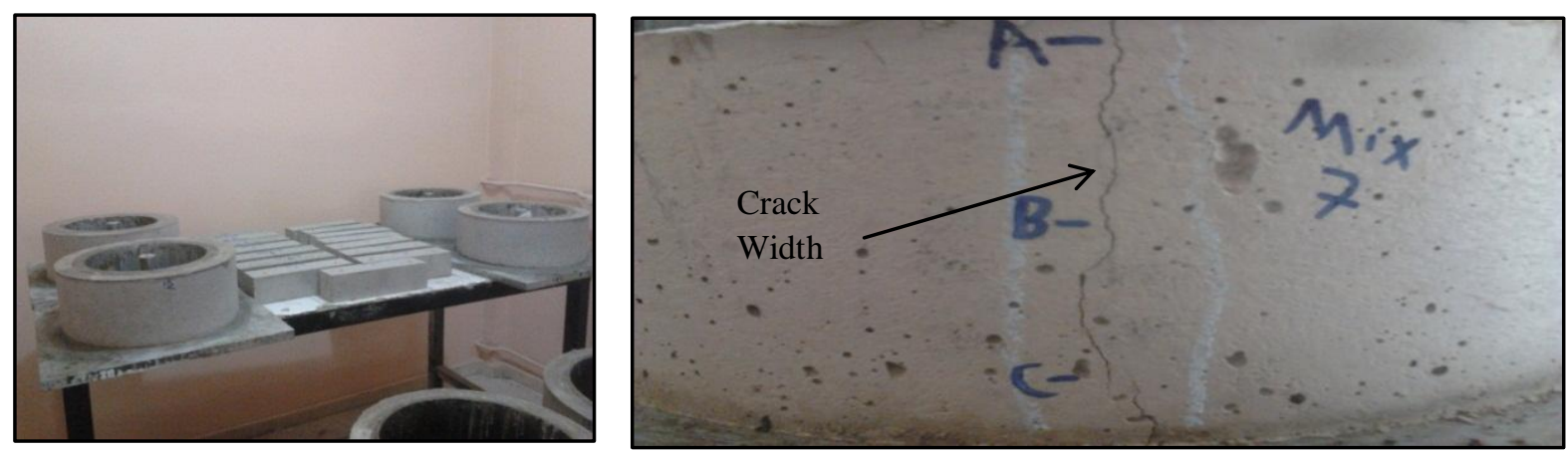

(a) 


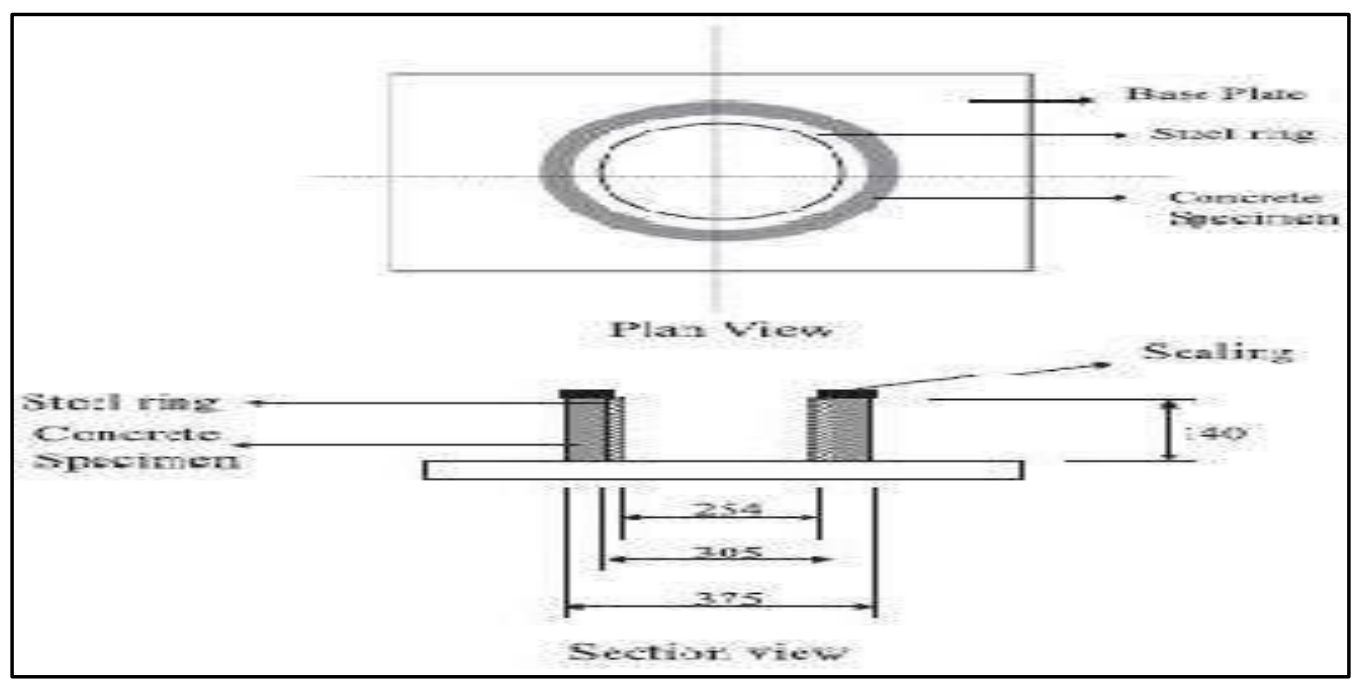

(b)

Fig. 5:- Restrained shrinkage cracking test: (a) photographic view of restrained and free shrinkage specimen and cracked rig specimen for mix 7(RFGA0RCGA20), and (b) dimensions of a restrained shrinkage ring specimen (in $\mathrm{mm})$.

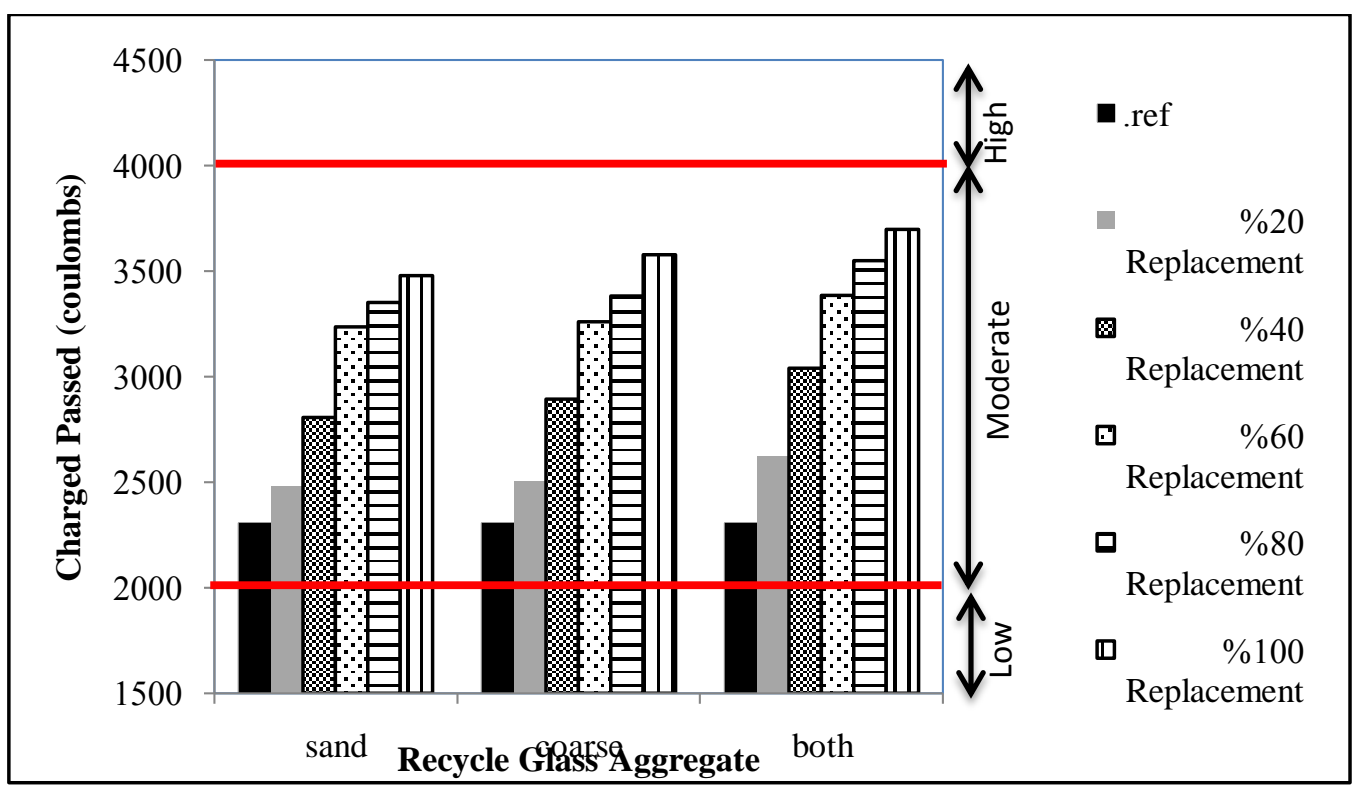

Fig 6:-Chloride ion permeability variations of self-compacting concretes with recycled glass aggregate contents. 


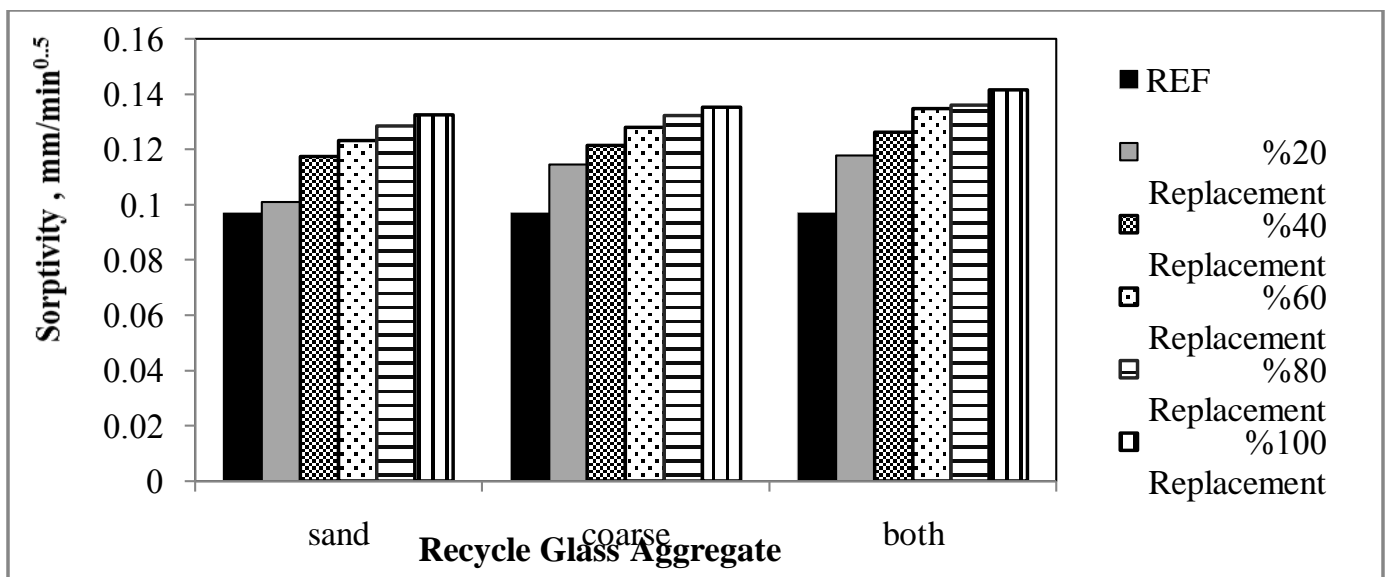

Fig.7:-Water sorptivity variations of self-compacting concretes with recycled glass aggregate contents.

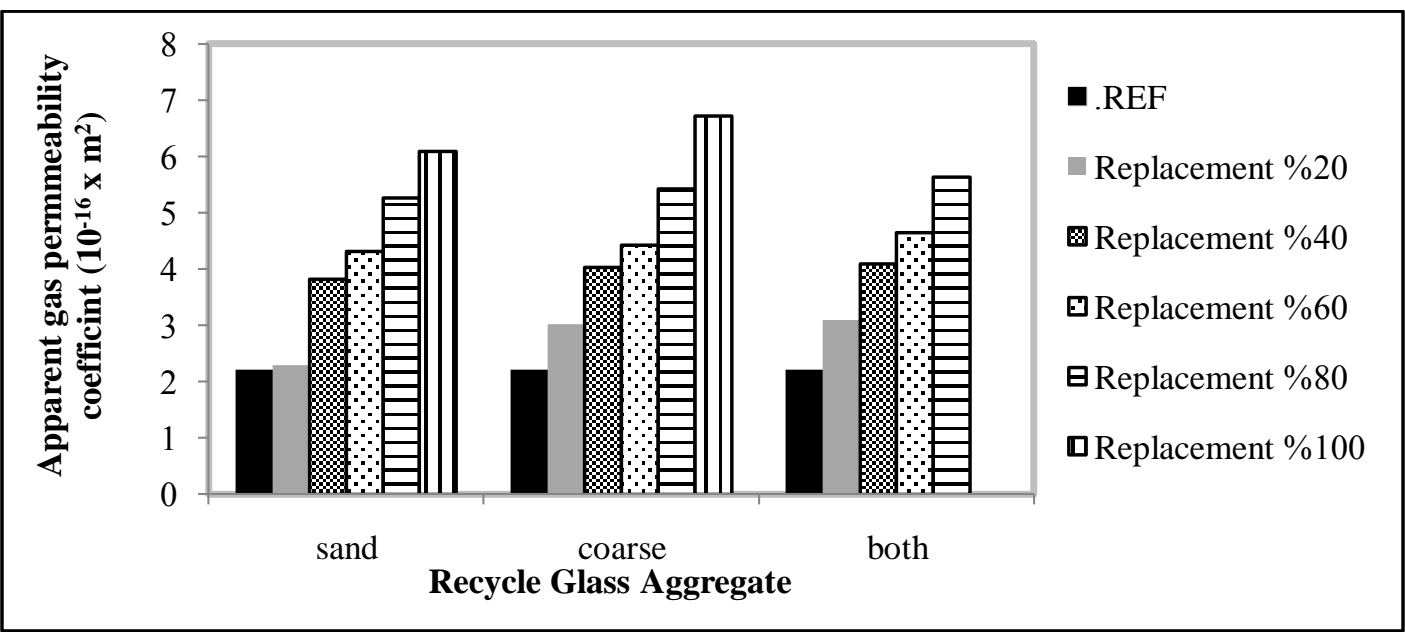

Fig8:-Gas permeability variations of self-compacting concretes with recycled glass aggregate contents.

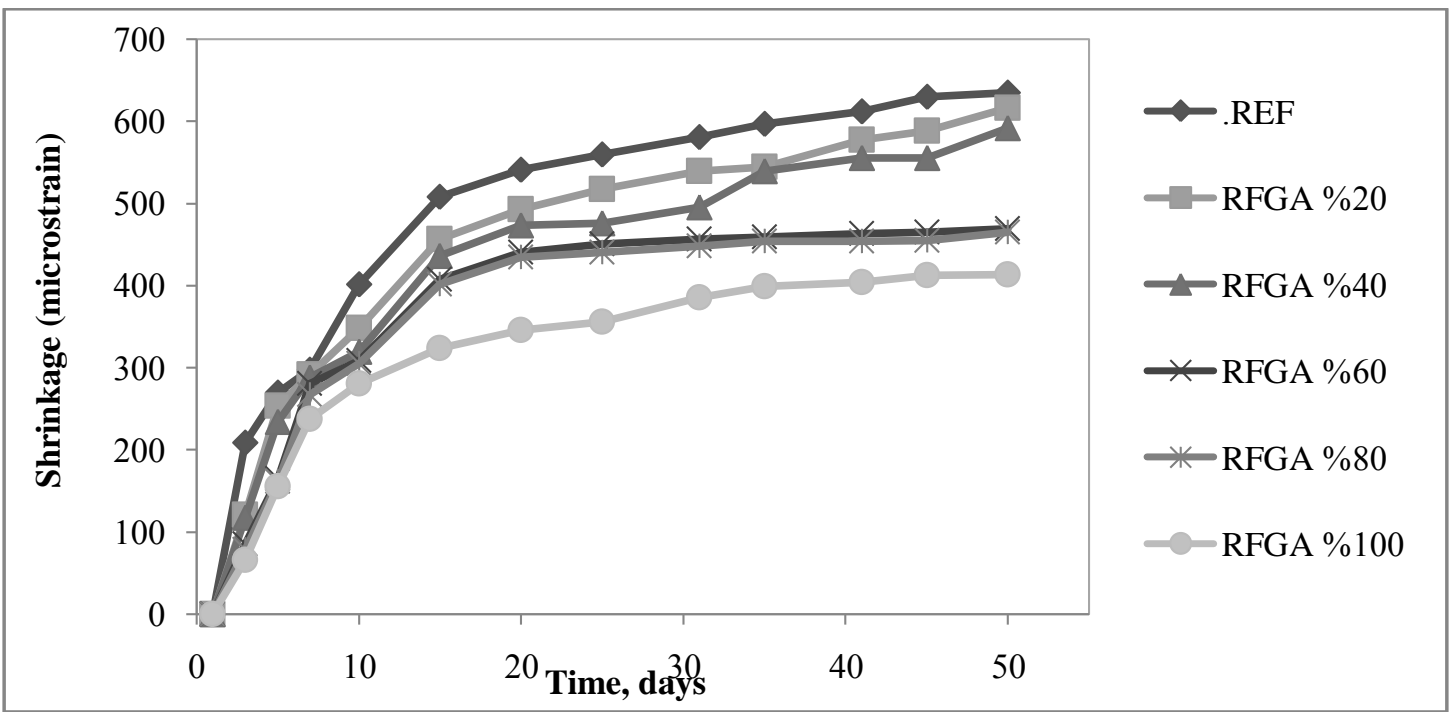

(a) 


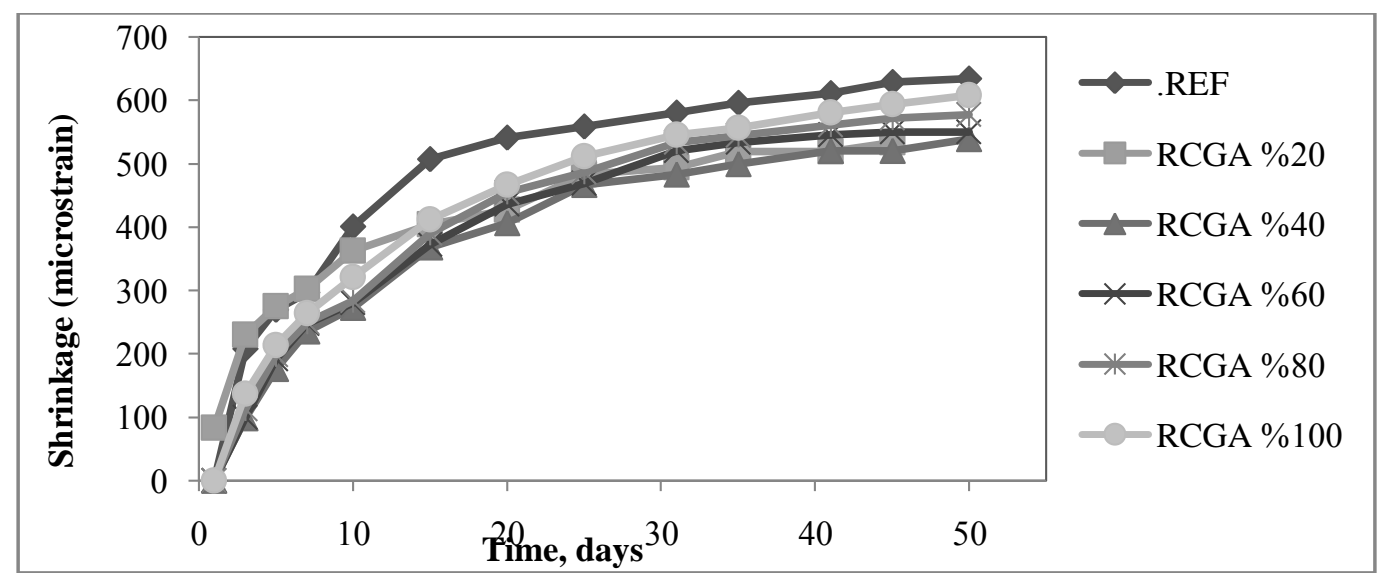

(b)

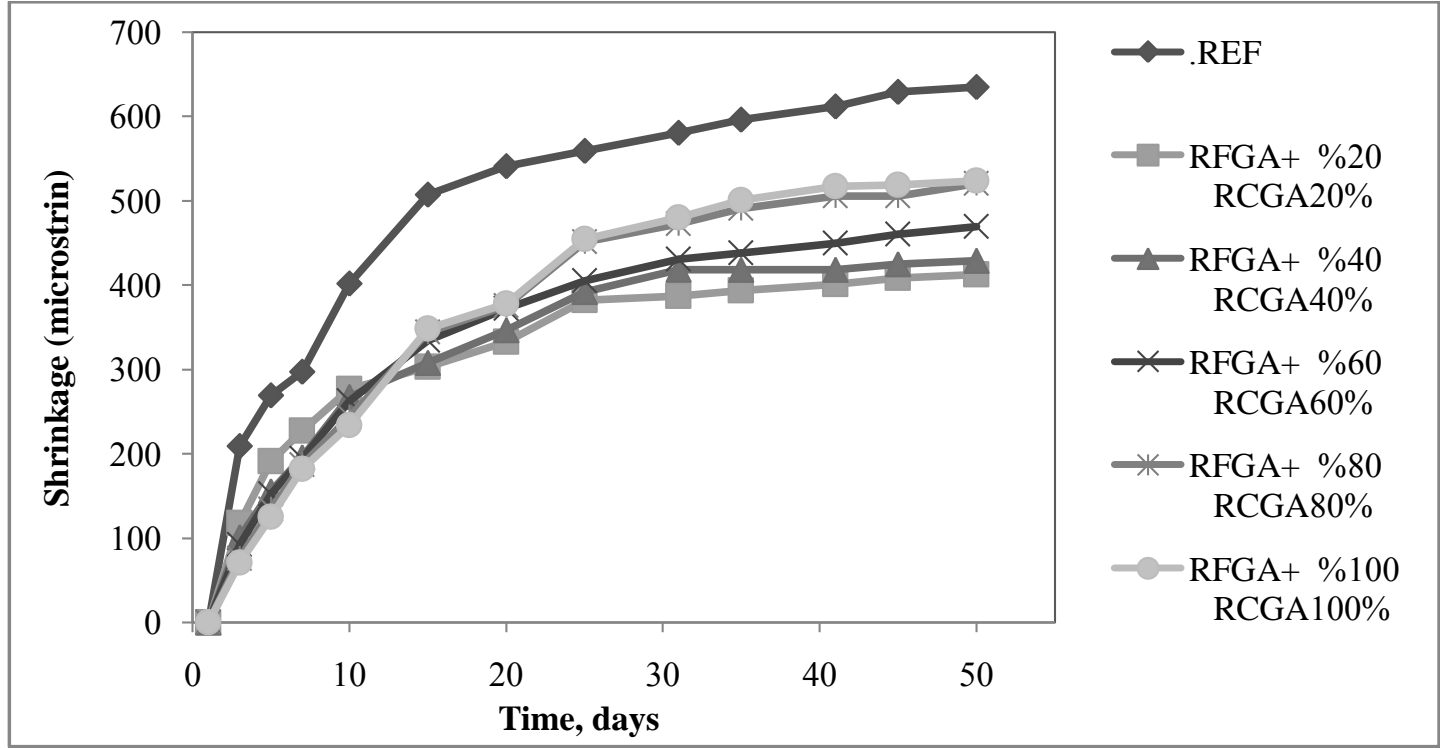

(c)

Fig.9Drying shrinkage for SCCs according to type of replacement of aggregate: (a) fine aggregate (Series I), (b) coarse aggregate (Series II), and(c) both fine and coarse aggregate (Series III) 


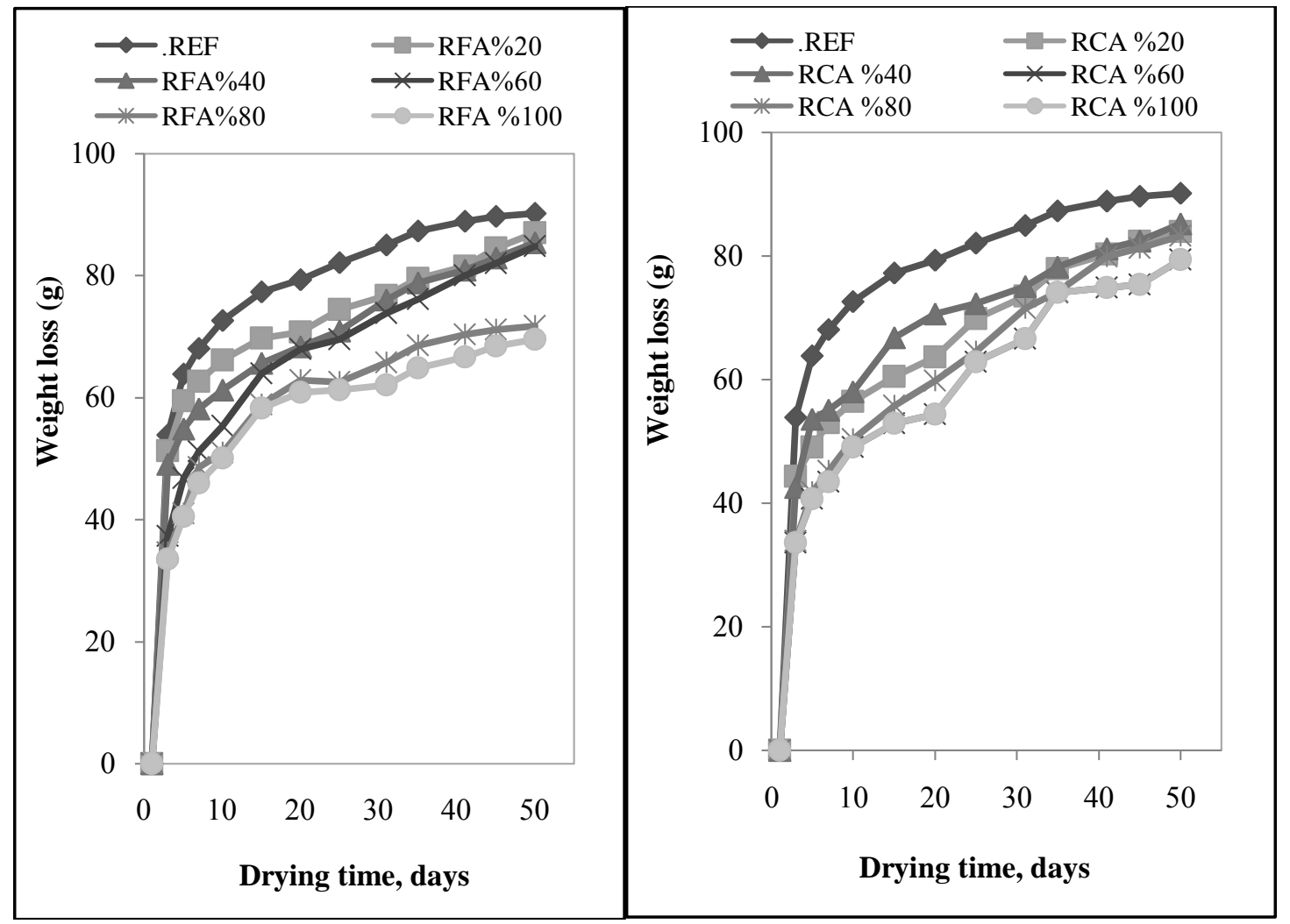

(a)

(b)

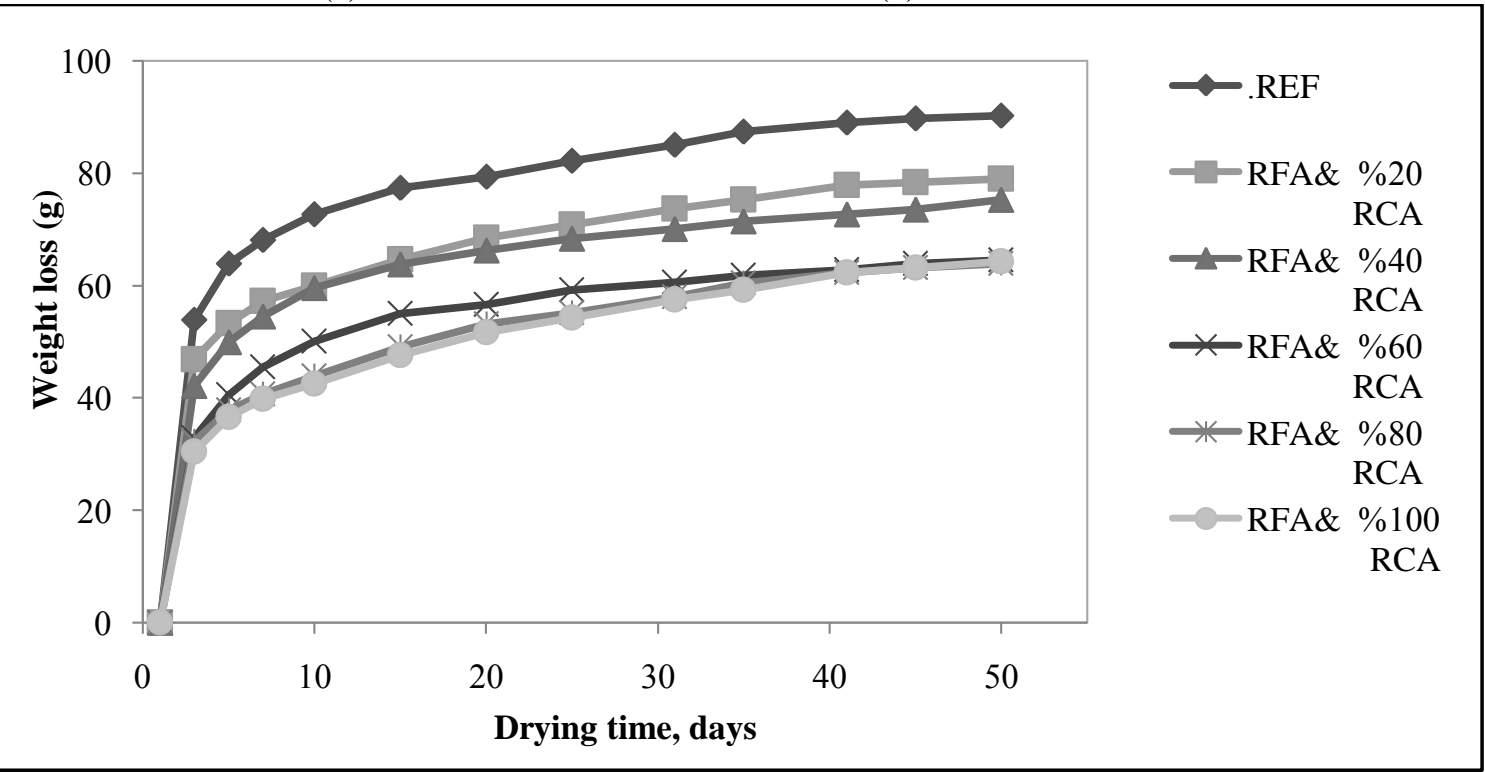

(c)

Fig.10:-Weight Loss for SCCs according to type of replacement of aggregate: (a) fine aggregate (Series I), (b) coarse aggregate (Series II), and(c) both fine and coarse aggregate (Series II) 

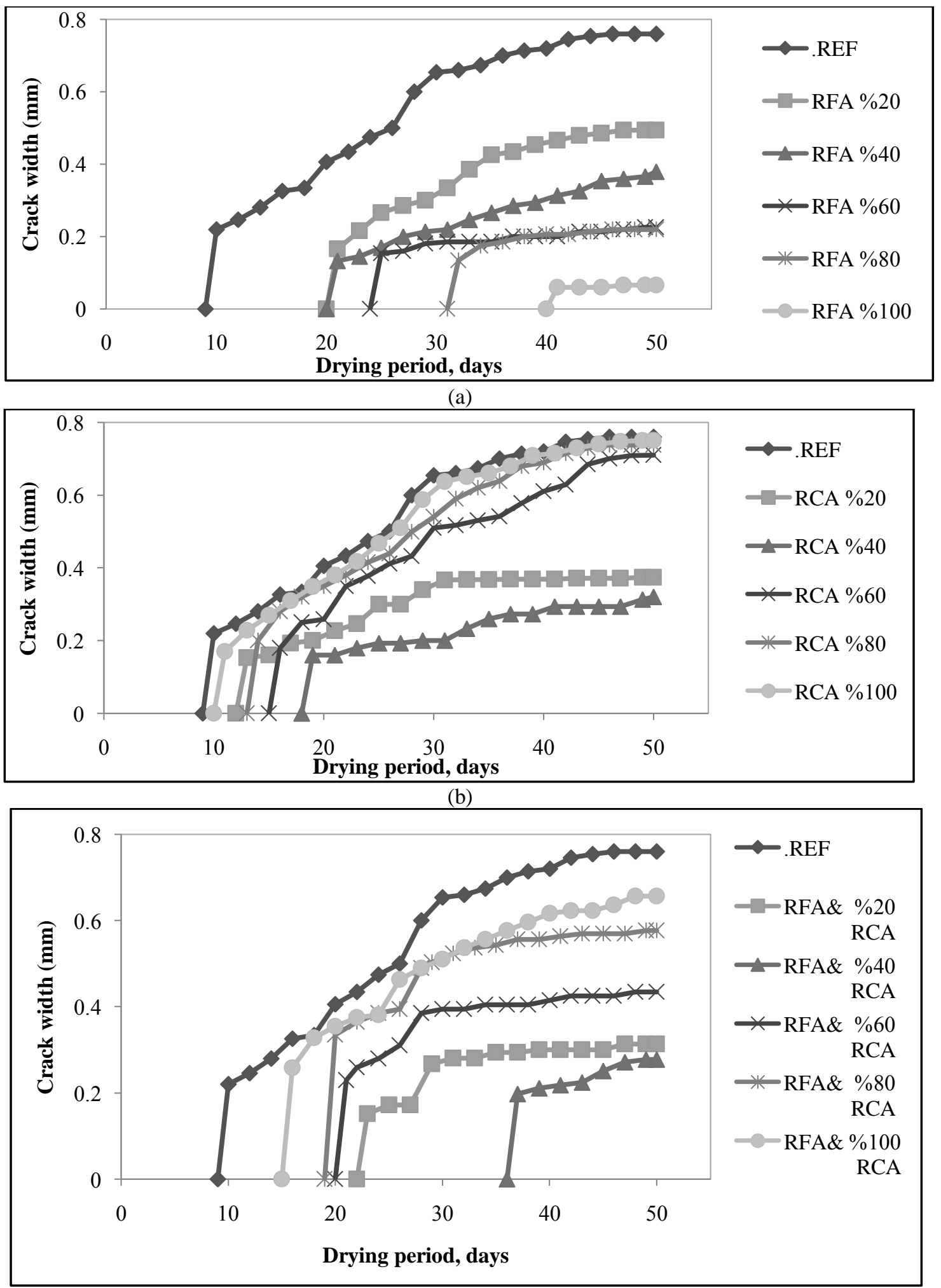

(c)

Fig.11:-Restrained Shrinkage for SCCs according to type of replacement of aggregate: (a) fine aggregate (Series I), (b) coarse aggregate (Series II), and(c) both fine and coarse aggregate (Series III) 


\section{Results and Discussion:- \\ Rapid chloride permeability:-}

Rapid chloride permeability test results at 28 days age for SCGCs were graphically presented in Figure 6 . As shown in Figure 6, the results of rapid chloride permeability of all concretes classified as moderate according to Table 5. The results from Figure 6 showed that, the incorporation of recycled glass to SCCs affected in a negative way on the total charges passed, for instance the total charges passed through the control mixture was 2305.4 coulombs. While in the $1^{\text {st }}$ series the total charge ranged from 2482.62 to 3478.12 coulombs, the total charge in the $2^{\text {nd }}$ series was 2504.34 to 3577.14 coulombs, and in the $3^{\text {rd }}$ series the total charge was between 2623.5 and 3697.25 coulombs, these results for replacement of natural aggregate by recycling glass aggregate from 20 to $100 \%$. In general the chloride permeability increased with the raise of recycled waste glass content this behavior is due to the increase the amount of microcracks within the recycled glass during crushing process. However, the rate of increase of total charged in the first series (replacement of fine aggregate) was less than that in second series (replacement of coarse aggregate) for example, the increase within $1^{\text {st }}$ series was $34 \%$ while, at the $2^{\text {nd }}$ series was $36 \%$ and the rate of increase at $3^{\text {rd }}$ series was $60.5 \%$ this behavior may be attributed to increase the amount and sizes of microcracks because when the particles of recycled glass increase the size of microcracks increases. These results are conflicted with the results obtained by Kiang andHongjian [21], who reported that the total charges passed decrease to 69\% when use 50\% green recycle glass as sand in mortar. Kou and Poon showed that there is a decrease of $60 \%$ in the charge passed with $45 \%$ replacement of recycled glass as fine aggregate [7] since, the recycled fine glass aggregate which was used in this article coarser than that used with other research.

\section{Sorptivity index:-}

Water sorptivity test measured the rate of water movement into the concrete samples under the action of capillary forces [22]. The water sorptivity of a concrete surface depends on many factors which consist of: mixtures proportions, chemical admixtures and supplementary, cementitious materials presence, entrained air, the age and type of curing, the physical characteristics and composition of the cementitious material and aggregate, the degree of hydration, microcracks existence, and placement method. Also, moisture condition of concrete at the time of test effects on the sorptivity results [23].

Figure 7 represents the sorptivity coefficient of self-compacted glass concrete depending on the replacement proportions of recycled glass and type of replacement. The test results showed that, the replacement of recycled glass aggregate instead of natural aggregate increases the sorptivity coefficients. This behavior may be attributed to angular shape, and sharp edge of recycled glass which lead to increase the amount of air and that lead to increase the porosity due to increase the amount and continuity of air within the concrete structure also, this increase of sorptivity may be due to capillary absorption of SCGCs. Also Figure 7 showed that, the sorptivity coefficient of RCGAs concrete was higher than that for RFGAs concrete due to increase the size of air bubbles between recycled glass aggregate particles for example, the sorptivity coefficient for control mix was $0.0971 \mathrm{~mm} / \mathrm{min}^{0.5}$ compared to $(0.123$, 0.128 and $0.135 \mathrm{~mm} / \mathrm{min}^{0.5}$ ) $\mathrm{mm} / \mathrm{min}^{0.5}$ at $60 \%$ replacement of fine, coarse, and both respectively.

\section{Gas permeability:-}

The apparent gas permeability was compute according to Hagen-Poiseuille relationship for laminar flow of a compressible fluid through a porous body with small capillaries under steady-state conditions [24]. As requested by RILLIM [18], the average gas permeability coefficient was calculated by using 150,200 , and $300 \mathrm{kPa}$ inlet pressures. Figure 8 explains the gas permeability coefficients of SCGCs tested at 28 days.

As shown in Figure 8, the gas permeability coefficient increased with increases of recycled waste glass content. For example, the gas permeability coefficient of reference mixture was $2.19852 \times 10^{-16} \mathrm{~m}^{2}$ compared to (2.29584-6.0892) $\times 10^{-16} \mathrm{~m}^{2}$ from 20 to $100 \%$ fine aggregate replacement, and $(3.023-6.7243) \times 10^{-16} \mathrm{~m}^{2}$ for $20-100 \%$ coarse aggregate replacement. While, for both replacements the gas permeability coefficient was between 3.08843 and $5.6345 \times 10^{-16}$ $\mathrm{m}^{2}$ for $20-80 \%$ replacement. However for RFGA100RCGA100 replacement (Mix 16,100\% replacement of NFA and NCA by RFGA and RCGA) cannot be measured because the amount of air was very large. It can be seen that the same trend of sorptivity index was return back for gas permeability coefficients. This behavior is due to increase pore structure and size of pores in concrete with increased the recycled glass content since the glass has angular shape, and sharp edge. Also, maybe there is another reason; the presence of water within the concrete structure, this existing water which is because of the little absorption of recycled glass and after heating in the oven this water turns in to pores which leading to increase gas permeability coefficients. 


\section{Drying shrinkage and weight loss:-}

It can be defined as the volumetric changes due to drying of concrete. The mechanism of drying shrinkage, start when the concrete lost its free water and as the drying of concrete continues, the adsorbed water is removed. The absence of this water cause tensile stress, which lead to shrink. The drying shrinkage depends on many factors such as: w/c ratio, degree of hydration, relative humidity, curing temperature, aggregate properties, admixtures, duration of drying, and cement composition [25].

The relationship between drying shrinkage and time for SCCs containing recycled glass are drawn in Figure 9 (a, b, and c) It was seen from these Figures that all the SCGCs showed a stable shrinkage after 30 days.

Also, it can be noted that the drying shrinkage at 50 days for all mixtures were less than 750 microstrain according to Australian Standard AS 3600[26] for all concrete mixes. Figure 9 showed that the drying shrinkage decreases with increases the amount of recycled glass as fine aggregate in series 1, for instance, the drying shrinkage at the end of 50 day for control mixes was 634.7 microstrain compared to 616-412.8 microstrain for 20-100\% RFGA (series I). This reduction in drying shrinkage values maybe attributed to existence of water within the concrete structure because the absorption of glass is too little so the hydration process continues without the need to use the water hold by gel pores and that lead to self-desiccation decreases. Finally, the total shrinkage will decrease. Many researchers have reached the same results when using recycled glass as aggregate [7, 9, 20 and 21]. But, the drying shrinkage in series II and III begins to increase when the recycled coarse glass aggregate was more than $40 \%$ due to the decreasing the amount of natural coarse aggregate until it completely disappear and replaced by recycled coarse glass aggregate and this recycled coarse glass aggregate have less modulus of elasticity than natural coarse aggregate. For example the drying shrinkage for 20-100\% RCGA (series II) ranges between 533.5 to 608.9 microstrain; and for both replacements (series III) it ranges between 412.8 to 524.2 microstrain.

Figure10 (a, b, and c) are shown the results of weight loss with time of drying due to drying shrinkage for different type of aggregate and replacement. In general SCCs consist of recycled glass exhibited a lower weight loss compared with reference mix since the recycled glass aggregate have low water absorption compered to natural aggregate. For example, the weight loss for control mix was $90.2 \mathrm{~g}$ at the end of 50 days of drying compared to 69.6, 79.4 , and $64.3 \mathrm{~g}$ for $100 \%$ replacement of fine, coarse, and both respectively at the same period of drying.

\section{Restrained shrinkage:-}

The cracking of concrete is predictable when the tensile stress which induced by restricted the free shrinkage excesses its tensile strength [24]. Figure11 (a, b, and c) explained the crack progression and the shrinkage cracking age of the restrained shrinkage samples for three series of recycle glass with different replacement, it can be noted from these Figures that all the concrete mixtures showed a stable shrinkage after 30 days.

As shown in Figure11, recycled glass aggregate positively affect the restrained shrinkage cracking performance of SCCs when it replaced as fine aggregate and when used as coarse aggregate with less than $60 \%$ of replacement, its effect on the time to initiate to crack and on the crack width. It can be seen that, the initial cracking of control samples was observed at the $10^{\text {th }}$ day after mixing. However, the cracks were observed after 21-41 day after mixing in series I for different replacement. The presence of water causes these results because the absorption of recycled glass is too little so the hydration process continues without the need to use the water located in gel pores and also, due to the presence of natural coarse aggregate which eliminate the movement of restrained concrete. While, it observed after 13-11 day and 23-16 day after mixing for series II and series III respectively, this occur because of the absence of natural aggregate.

Also from Figure11, it can be seen that the replacement of natural aggregate by recycled glass aggregate reduces the crack width of SCCs compared to control mixture. For instance, the ratio of decreasing in the crack width was 35 to $51.8 \%$ in the $1^{\text {st }}$ series at the end of 50 day. While it decreased from 50.8 to $55.3 \%$ when the recycled coarse aggregate increase from 20 to $40 \%$ in series II but, after that the ratio of crack width began to decrease till it reached $1.3 \%$ at $100 \%$ replacement of RCA at the end of 50 day. The same relation was recognized in series III the ratio of crack width decreased from 58.7 to $63.4 \%$ when the recycled fine and coarse aggregate increase from 20 to $40 \%$ in series III but, after that the ratio of crack width started to decrease so it amounted to $13.6 \%$ at $100 \%$ replacement of RFA \& RCA at the end of 50 day. The decrease in free shrinkage may be lead to decrease the cracking width of SCCs containing recycled glass as fine aggregate and when used recycled glass as aggregate with less than $60 \%$ but, the absence of natural aggregate lead to increase the crack width. 


\section{Conclusions:-}

Based on the result obtained from this study, the following conclusions may be drawn:-

- A progressive increase was observed in the chloride ion penetration of the self-compacting glass concretes with the increase in recycled glass aggregate content at 28 days test results.

- Since the presence of the recycled glass aggregate in the concrete, porosity is poorly affected. Therefore, water sorptivity values of the self-compacting glass concretes increased.

- Increase amount of recycled glass aggregate lead to increase the apparent gas permeability of self-compacting concrete.

- Drying shrinkage of self-compacting concretes decreases with increases the recycled glass aggregate. Although, the drying shrinkage decreased with increased the recycled glass aggregate as fine aggregate and when used recycled coarse aggregate and both of them at less than $60 \%$ of replacement but, the drying shrinkage increased after that at the end of 50 days.

- Also, the weight loss of SCCs reduces with the replacement of recycled glass aggregate instead of natural aggregate after 50 days drying.

- In general replacing the recycled glass aggregate instead of natural aggregate decrease the restrained shrinkage compared to control mixture. Though, this relation applies when using recycled glass aggregate as fine aggregate and used recycled coarse aggregate and both of them at less than $60 \%$ of replacement. But, this decreasing began to reduce after that at the end of 50 days drying period.

- At the same time, the replacement of recycled glass aggregate instead of natural aggregate delay the crack observation of SCCs. But this delay depends on the replacement ratio and on the type of the replacement after 50 days drying condition.

\section{References:-}

1. Her-Yung Wang and Wen-Liang Huang,"A study on the properties of fresh self-consolidating glass concrete (SCGC)",Construction and Building Materials24 (2010), pp. 619-624.

2. Topçu, I. B. and Canbaz M., "Properties of concrete containing waste glass", Cement and Concrete Research 34(2004), pp. 267-274.

3. Hongjian Du and Kiang Hwee Tan," Use of waste glass as sand in mortar: Part II - Alkali-silica reaction and mitigation methods", Cement \& Concrete Composites 35 (2013), pp.118-126.

4. CihatYuksel, Reza SalehAhari, BabakAbbaspoursaniAhari, and KambizRamyar," Evaluation of three test methods for determining the alkali-silica reactivity of glass aggregate", Cement \& Concrete Composites 38 (2013), pp. 57-64.

5. Meyer, C., "Glass concrete", Concrete International 25 (6), 2003, pp.55-58.

6. Ducman, V., Mladenovic, A., and Suput, J.S.," Lightweight aggregate based on waste glass and its alkali-silica reactivity", Cement and Concrete Research 32 (2002), pp.223-226.

7. Kou SC, and Poon CS," Properties of self-compacting concrete prepared with recycled glass aggregate", CemConcr Compos 31(2) 2009, pp.107-113.

8. Dhir, R. K., Dyer, T. D, Tang, A., Cu, Y. J. and Wang, L.," Towards maximising the use of glass cullet in concrete, Concrete technology unit", Concrete London 39(8), 2009, pp.32-34.

9. Ling, T. C., Poon, C. S., Kou, S. C.,"Feasibility of using recycled glass in architectural cement mortars", Cement and Concrete Composites 33(8), 2011, pp.848-854.

10. TS EN 197-1, Cement- Part 1: Composition, specifications and conformity criteria for common cements, Turkish Standards, 2002.

11. ASTM C 127, Standard test method for specific gravity and absorption of coarse aggregate, in: Annual Book of ASTM Standards, 2007.

12. TS 706 EN 12620-A1, Aggregates for concrete, Institute of Turkish Standards, Turkish Standards, 2009.

13. ASTM C 192, Standard practice for making and curing concrete test specimens in the laboratory, in: Annual Book of ASTM Standards, 2007.

14. Khayat KH, Bickley J, and Lessard M.," Performance of self-consolidating concrete for casting basement and foundation walls". ACI Mater J 2000; 97, pp.374-380.

15. ASTM International, ASTM C157, "Standard Test Method for Length Change of Hardened Hydraulic-Cement Mortar and Concrete", Annual Book of ASTM Standards, ASTM International, West Conshohocken, Pa, USA, 2007.

16. ASTM International, ASTM C1202, "Standard test method for electrical indication of concrete's ability to resist chloride ion penetration", 2009. 
17. A. Kanellopoulos, D. Nicolaides, andM. F. Petrou, "Mechanical and durability properties of concretes containing recycled lime powder and recycled aggregates", Construction and Building Materials 53(2014), pp. 253-259.

18. RILEM, "TC 116-PCD. Permeability of concrete as a criterion of its durability", Materials and Structures, 32(1999), pp.174-179.

19. K.Wiegrink, S. Marikunte, and S. P. Shah, "Shrinkage cracking of high-strength concrete", ACI Materials Journal, vol. 93, No. 5(1996), pp. 409-415.

20. S. P. Shah, M. E. Karaguler, and M. Sarigaphuti, "Effects of shrinkage-reducing admixtures on restrained shrinkage cracking of concrete" , ACI Materials Journal, vol. 89, No. 3, pp. 289-295, 1992.

21. Kiang Hwee Tan and,Hongjian Du," Use of waste glass as sand in mortar: Part I - Fresh, mechanical and durability properties", Cement \& Concrete Composites35 (2013), pp. 109-117.

22. P. Suvash and Z. Gideon,"Mechanical and durability properties of recycled concrete aggregate for normal strength structural concrete", International Journal of Sustainable Construction Engineering \& Technology 4(1), 2013, pp. 89-103.

23. ASTM C1585-4," Standard test method for measurement of rate of absorption of water by hydraulic cement concretes", 100 barr harbor drive. PO Box C700, West Conshohocken (PA); 2004.

24. Mehmet Gesoglu, ErhanGüneyisi, HaticeÖznurÖz, Mehmet TanerYasemin, and IhsanTaha,"Durability and Shrinkage Characteristics of Self-Compactin Concretes Containing Recycled Coarse and/or Fine Aggregates",Hindawi Publishing Corporation, Advances in Materials Science and Engineering, Volume 2015, Article ID 278296, 18 pages.

25. A.M.Nivell, "PROPERTIES OF CONCRETE", $4^{\text {th }}$ and Final edition.

26. AS 3600," Concrete structures-incorporating AMD 1: May 2002 and AMD 2", Australia Standard, October 2004. 